\title{
Sustainability education and social inclusion in Nordic early childhood education
}

\begin{abstract}
This article explores the relations and tensions between sustainability education and social inclusion in the context of Nordic early childhood education. Based on ethnographic field studies of ecological sustainability education in socially vulnerable neighborhoods, we discuss how a focus on access to nature experiences and nature education appears to overlook societal mechanisms of exclusion, which frame and get entangled with sustainability education activities. This, we argue, becomes a barrier for inclusive sustainability education, but it also prevents attention being paid to ambivalent emotions connected with relations to nature that could be a key to developing further the content of early childhood sustainability education.
\end{abstract}

Keywords: Sustainability education, early childhood, social inclusion, Scandinavia, sameness, ambivalence

\section{Zusammenfassung}

Dieser Artikel untersucht die Beziehungen und Spannungen zwischen Nachhaltigkeitsbildung und sozialer Integration im Kontext der nordischen frühkindlichen Bildung. Basierend auf ethnographischen Feldstudien zur ökologischen Nachhaltigkeitsbildung in sozial gefährdeten Nachbarschaften diskutieren wir, wie ein Fokus auf den Zugang zu Naturerfahrungen und Naturbildung gesellschaftliche Ausgrenzungsmechanismen zu übersehen scheint, die Aktivitäten der Nachhaltigkeitsbildung einrahmen und mit diesen verflochten sind. Dies, so argumentieren wir, wird zu einer Barriere für eine inklusive Nachhaltigkeitsbildung, aber es behindert auch die Aufmerksamkeit für ambivalente Emotionen in den Naturbeziehungen, was ein Schlüssel zur Weiterentwicklung der Inhalte frühkindlicher Nachhaltigkeitsbildung sein könnte.

Schlüsselworte: Nachhaltigkeitsbildung, frühe Kindheit, soziale Integration, Skandinavien, Gleichheit, Ambivalenz

\section{Introducation}

In the school garden, children from a nearby day care institution situated in an underprivileged neighborhood are cooking chicken soup over a fire. While the soup is cooking, Aysha, Yasmin and Nadja are digging with their bare hands in the soil, looking for earthworms for the chickens roaming freely in the garden on this autumn day. They laugh and talk as they get hold of a worm and Yasmin places it on her palm. Ann, the social educator ${ }^{1}$ accompanying them, calls to the children from a distance, telling them that the soup is ready. Aysha looks at her hands and at her jacket, which has got dirty while they were playing, trying to brush of the soil. Then she goes over to Ann to tell her that she wants to wash her hands before eating. Ann responds somewhat sharply that a bit of dirt never did anybody any harm.

(Edited field notes, November 2018)²

In this article, drawing on ethnographic research in school gardens involving young children, we discuss the challenges and opportunities related to addressing the question of social inclusion in early childhood sustainability education in a Danish context.

Vegetable gardens are widespread in Denmark and provide entry points for sustainability education in day care institutions. In raised beds on playgrounds in day care institutions, and in larger gardens hosted by NGOs or municipal actors, 1-6-year-old children are offered the opportunity to get their hands dirty and get involved in so-called "soil-to-table" (jordtil-bord) learning activities. The school garden described in the introductory field note is situated in the greater Copenhagen area and runs summer and winter programs, with weekly visits to the garden for groups of children from day care institutions in the vicinity. According to the NGO hosting the garden, gardening is a way to teach children about ecological sustain- 
ability: "Through learning by doing, the children learn how to behave respectfully in nature, as well as learning where food comes from. The children are taught about the diversity of animals and plants and their own role in the circle of life" (Sustainia \& Realdania, 2018, p. 44). Furthermore, it is a key ambition of the school gardens to involve in their activities children who are in vulnerable situations: "All children deserve to know what they are eating" (Mauritzon, 2018), explains the manager of the school garden in an interview. In line with many other nature education practitioners in Denmark, the staff of this particular school garden point out that children from low-income ethnic minority families enjoy fewer "nature experiences" than other children, and emphasize the need to pay greater attention to social inclusion in nature and outdoor education. However, as we will show in this article, ambitions of inclusion in sustainability education in the Danish context are often paradoxically entangled with implicit expectations of socio-cultural sameness. This places educators in situations characterized by dilemmas, in particular when working with minority children from immigrant backgrounds. When, as described in the field note, Aysha worries about her dirty clothes, her actions clash with cultural expectations as to children's behavior in, and relations to, "nature". This behavior is supposed to be characterized by a "natural" and playful openness and innocence, rather than fear of, or being disgusted by, disgust with dirt, which is why she is reproved by the social educator.

As described in regional ethnographic literature in Scandinavia, the Nordic welfare states are characterized by a high socio-cultural valuation of "equality". On the one hand, in the Scandinavian welfare states, equal rights and access to social services such as education have been guiding principle for the organization of the welfare state (Bruun, 2018). On the other hand, as famously argued by the Norwegian anthropologist, Marianne Gullestad, equality in Scandinavia is often conceived as sameness in everyday life practices (what she refers to as "imagined sameness"), and this cultural valuation of sameness has had a strong influence on the reception of immigrants (Gullestad, 2002; see also Bruun, 2018). In the field of early childhood education, a number of ethnographic and culturalanalytical studies have shown that in spite of the ambitions of equal access $^{3}$ and social inclusion, expectations of cultural sameness in interactions between early childhood social educators and children and their families result in processes of exclusion from participation (Bregnbæk, Arent, Martiny-Bruun \& Jørgensen, 2017; Bundgaard \& Gulløv, 2008; Palludan, 2007; Prins, 2019).

Our discussion addresses the consequences of this cultural valuation of sameness, in an attempt to bring together two policy and research agendas which for long have been discussed in two separate domains: social inclusion and ecological sustainability. In the first sections of the article, we present the methodology underlying our analysis, and situate our argument within policy and research debates concerning social inclusion and early childhood sustainability education, and within the context of Danish early childhood educational practice. After this, we discuss dilemmas related to the social inclusion of minority children in ecological sustainability education, exploring ways in which processes of social inclusion and social exclusion relate to each other in this specific pedagogical con- text (Hamre \& Larsen, 2016, p. 9). With inspiration from discussions of cultural notions of sameness (Bruun, 2018; Gullestad, 2002), we explore how expectations of sameness in children's relations to nature may account for unintended practices of social exclusion of children (and families) with minority backgrounds, even when social inclusion is an explicit ambition. We argue that these cultural expectations of sameness in terms of relations to nature more generally exclude "other" kinds of relation to nature and propose that inclusive sustainability education in early childhood requires attention to human differences, but also to heterogeneity and ambivalence in emotional relations to nature.

\section{Methodology}

The article is based on a research project on sustainability education anchored by the Department of Social Education at the University College Copenhagen. Based on critical and constructive approaches, the project aims to explore and support the development of early childhood sustainability education in the Danish context. The project aimed to explore and support the development of early childhood sustainability education in the Danish context. The project involved explorative and collaborative research activities with teachers and students as well as with practitioners and children in various educational settings (early childhood institutions and activities run by NGOs). The research methodologies combined action research (Husted \& Tofteng, 2014; Nielsen \& Svensson, 2006) and engaged anthropology (Low \& Merry, 2010; Nielsen \& Jørgensen, 2018). The action research component of the project focused on educational experiments and co-created knowledge production related to sustainability education in processes involving researchers, teachers and students. Parallel to, and in dialogue with these processes, an ethnographic study was made of nature pedagogies and sustainability education activities with young children from social housing areas. The two "paths" of the project employed different research positions but shared an ambition to make a difference that goes beyond academic knowledge production, with the aim of engaging more directly in the promotion of social change.

The analyses underlying the discussions addressed in this paper are primarily based on empirical material generated in ethnographic fieldwork covering gardening and nature exploration activities involving children from social housing areas in the greater Copenhagen area. Our analytical approach may be characterized as abductive (Coffey \& Atkinson, 1996). Therefore, rather than deductively framing our empirical study with specific theories and concepts before the field work, or, inductively, building our conceptualizations solely on phenomenologically grounded empirical explorations that are subsequently related to existing theories, we have attempted to establish a continuous dialogue between empirical findings and theoretical conceptualizations. The analysis of empirical material has drawn on cultural analytical methods. We have identified themes, patterns and tensions in the larger empirical material ( Ehn \& Löfgren, 2010), brought these into dialogue with theoretical concepts, and then, based on this first analytical move, identified key cases for further analysis and discussion. 
In terms of theory we have been inspired by anthropological perspectives on social inclusion and migration in education (e.g., Palludan, 2007), and by social psychological and anthropological discussions of ambivalence in everyday life and learning (e.g., Illeris, 2004; Leithäuser, 1976; Mason, 2018). Analytically, our starting point is the notion of "imagined sameness" described by Gullestad as a cultural "logic" and an "interaction style in which commonalities are emphasized while difference is played down" (Gullestad, 2002, p. 47). The notion of sameness constitutes a useful analytical lens for exploring how minority children and their parents are expected to adapt to specific educational forms and practices, but also for understanding the ways in which children's emotional ambivalences in relation to nature are excluded from or overlooked in the educational space.

\section{Conceptualizing social inclusion in early childhood sustainability education}

As discussed in Rieckmann and Vierbuchen's article (this issue), in terms of the Sustainable Development Goals (SDGs), the policy agendas of Education for Sustainable Development and of inclusive education, which until recently have been following two different paths, have been combined in SDG 4, which identifies inclusive quality education, including preprimary education, as a foundation for sustainable development (United Nations, 2015).

Sustainability, as defined since the so-called Brundtland report, "Our common future" (WCED, 1987), explicitly addresses a social dimension and underlines the importance of rethinking economic development in the light of ecological and social issues such as inequality, inclusion and diversity. Yet, in practice, this broad (sometimes referred to as "holistic") notion of sustainability has constituted a challenge to educational and research approaches, which historically have attempted to deal with subject matters such as "nature", "society" or "economy" as separate domains (Jørgensen, forthcoming; Læssøe, forthcoming).

In the field of critical research on environment and sustainability education research in Denmark, the concept of action competence (Schnack, 2000) with its focus on democratic ideals, Bildung, global inequality and participation in relation to environmental education, could be seen as an attempt to address questions of social inclusion in sustainability education. While critical environmental education research in Denmark has primarily focused on schools and civil society and not much on early childhood education, the early childhood field has adopted the concept of action competence ( Edlev, 2015). However, it has done so, primarily, by paying attention to teaching children environmentally friendly behavior (Husted \& Frøkjær, 2019), and only to a limited degree through critical reflection on children's citizenship, engagement and barriers to participation, or educational activities that might address these issues.

Until recently, as argued by Davis (2009), sustainability education in early childhood constituted a research gap in the literature on the environment and sustainability education. However, as early as 2015, two reviews of the field pointed to a growing body of literature. According to Hedefalk, Almqvist
\& Östman (2015), more recent research on early childhood and sustainability has focused primarily on children's democratic participation, their outdoor experiences, their knowledge about the environment, and, to a lesser degree, their actions for change. Somerville and Williams (2015) have pointed to literature on children's connections to nature, children's rights and voice, and to new theoretical developments, in particular the rise of research informed by new materialist and post-humanist theory. More recently, in 2019, Boldermo and Ødegaard (2019) published a review focusing on how the social dimension is conceptualized in early childhood education for sustainability. Their work reveals that while children's democratic participation and citizenship is a recurrent theme, few articles have investigated the aspects of citizenship that relate to social inclusion and belonging, nor more generally to "diversity, multicultural perspectives, or migrant children's situation" (Boldermo \& Ødegaard, 2019, p. 1) in relation to sustainability education.

This article is an attempt to do exactly that, and to explore the tensions and dilemmas arising at the intersections between early childhood sustainability education and ambitions of social inclusion. While some of these tensions and dilemmas relate to more general tendencies in the European context, their actual configurations are connected to the local and regional empirical contexts in which they take place. Therefore, in the following we will briefly describe the roles and forms of social inclusion and sustainability education in the Danish early childhood context.

\section{Social inclusion and sustainability education in Denmark}

In Denmark, social inclusion in education has been on the agenda since the country signed the Salamanca Statement and Framework for Action on Special Needs Education in 1994, but the inclusion agenda primarily gathered force from the 2000s. ${ }^{4}$ While most discussions on inclusion have focused on primary schools, in recent years more attention has been given to inclusion in the context of day care institutions (Larsen \& Jørgensen, 2017).

The Danish Ministry of Education highlights inclusion as a pedagogical tool in Danish day care (0-6 years old), aiming to inhibit negative social heritage and exclusion (Børne- og Undervisningsministeriet, 2020). While social inclusion as a concept is not mentioned in the recent revision of the early childhood curriculum (2018), the curriculum mentions "inclusive learning environments" and "inclusive children's communities". Furthermore, it has a strong focus on "children in vulnerable positions" and underlines the need for organizing the educational environment in ways that support and accommodate the learning of children categorized as such (Børne- og Socialministeriet, 2018, p. 26). In the Danish context, social inclusion in early childhood education has often been understood as the opportunities all children have to participate in different communities within the institution, and thus involves a focus on participation, commonality and mechanisms of exclusion. This means that inclusion primarily has been addressed not through special intervention, but within and through general pedagogical practice. However, in recent years there has 
also been an increasing policy attention to social vulnerability as an individualized problem which requires early interventions in specific families by state actors (Houmøller, 2018)

While social inclusion is a key theme in education policy, until recently, this theme has only to a rather limited degree been connected to sustainability education in early childhood. In the 2018 curriculum, sustainability was introduced (for the first time) as a concept, but it is only mentioned in relation to the curriculum theme of nature, outdoor life and science, with an implicit focus on ecological sustainability (Børne- og Socialministeriet, 2018). In comparison, other Scandinavian curricula (e.g. Iceland and Sweden, see Ministry of Education Science and Culture, 2011; Skolverket, 2018) position sustainability as an overarching value, or foundational pillar of early childhood education, and include reflections on social sustainability - a concept which is not mentioned explicitly in the Danish curriculum.

Nature and outdoor life, on the other hand, have occupied an important place in the early childhood curriculum in Denmark since its initiation in 2004. The 2018 curriculum underlines the need for paying particular attention to the ambition of ensuring "that all children and families in vulnerable positions are supported in terms of being in, and learning about, nature" (Børne- og Socialministeriet, 2018, p. 44, our translation). In line with this, a number of civil society organizations and nature educators have used social work in nature contexts, based on arguments related to individual well-being and health, as well as to the effects on communal relations (Ejby-Ernst et al., 2018; Skytte, 2019).

In this article, we are interested in the educational openings and tensions of addressing social inclusion in early childhood sustainability education, and in the relations between such educational practice and wider societal processes. To discuss this further, we will go back to one of the educational sessions in the school garden.

\section{A dead chicken, nature, religion, and becoming ready for school}

In the school garden, one of the winter activities is slaughtering chickens. According to the nature educators working in the garden, slaughtering chickens is an important way to initiate discussions about food production, human-nature relations, life and death, etc. Other nature educationalists, such as the Danish nature guide and writer Lasse Edlev, emphasize the great development and learning-potential of discussions with children arising from the experience of death and killing (Edlev, 2016).

In this article, our main focus is not the question of killing or not killing, or more generally the use of animals for educational purposes, which, we are well aware, is a highly contested theme (Pedersen, 2019). Rather, in this context, we wish to look at the session as representing a specific version of Scandinavian approaches to nature and sustainability education, which allows us to explore some of the challenges, openings, and dilemmas arising when nature educators attempt to work with ecological sustainability education in socially inclusive ways. We will do this by discussing a situation that took place on a late autumn day in 2018, when eight of the oldest children from a day care institution situated in an underprivileged neighborhood were present in the school garden, together with a social educator from their institution. Most children in the early childhood institution were from ethnic minority families, their Danish language skills were perceived to be inadequate, and several of the children lived in families with different kinds of social problems. As part of an effort to include these children in the education system and ensure their transition to school the following summer, the day care institution had organized regular visits to the school garden in the vicinity, run by a local NGO with support from the local municipality.

\section{"Nature-foreign" children and parents - access and inclusion in the garden}

In the lower part of the large school garden, the children and a social educator from their day care institution were gathered in a circle around the nature educator, Peter, who prepared them for the activity of the day by discussing with them how we kill living things - animals and plants - in order to eat. He told them about how he helped his grandmother slaughter chickens as a child, and he emphasized that the chicken had had a good life in the garden, walking around freely. Then Peter picked the chicken from a cage, placed it on a chopping board and killed it by cutting off its head with an axe, while the children were watching in silence. He dipped it in boiling water and plucked off the feathers, cut it open and showed the children the intestines, discussing the names and colors. Afterwards, the children were involved in making a fire and cooking chicken soup over an open fire. Jørgensen's field notes from the session describes the subsequent interactions as follows:

Peter asks the children: "What can we do with a fire?" "Food", a child answers. Peter nods. From a plastic bag, he takes out a dead chicken, different from the one he had slaughtered, telling the children that he had bought it in the local bazar. It is halal. The children look at the chicken and start discussing, most of them saying that they are not allowed to eat it, one that he doesn't like chicken. The social educator from the day care institution confirms that they are all allowed to eat the chicken, that's why Peter bought it in the bazar. Peter says that someone else will eat the other chicken, the one that was slaughtered. "We should not kill animals just like that; we only kill them for eating. And killing another person is the worst crime."

(Edited field notes, November 2018)

In this situation, the nature educator had decided to adapt his sustainability education activity to ensure that it was accessible for minority children from Muslim families by exchanging the chicken he had just slaughtered with a halal-slaughtered chicken. In other words, Peter was occupied with ensuring social inclusion in the form of access to nature activities for children assumed to be lacking them, and attempted to ensure that no religious or cultural rules would block the children from participating fully in the activity, which is considered important for the educational processes in the school garden. Peter and his colleagues describe the rationale of the school garden 
as a contribution to ensuring that city children and, in particular, underprivileged children, are given the opportunity for nature experiences. While we do support the attention to outdoor activities in the Danish education system in general, and in early childhood education in particular, and while we do find Peter's pragmatic solution to the challenge related to religious rules quite practical, we propose that the situation described above indicates broader structures of social inequality and exclusion in Danish society and the education system which are not resolved by exchanging one dead chicken with another. As previously mentioned, in Scandinavia, equality is often understood as cultural sameness. Mikkel Rytter has argued that in Denmark, the expectation that immigrants should adapt as fast as possible to the cultural norms of sameness, paradoxically works to reinforce their otherness (Rytter, 2018). In the context of day care institutions, anthropological studies have shown that educational and institutional practices rationalized with reference to, for instance, health, well-being or learning, often reflect the middle class values and practices of the white majority (Bregnbæk et al., 2017; Palludan, 2007, Jørgensen \& Martiny-Bruun, 2019; Sparrman et al., 2016). Expectations of sameness mean that social differences related, for instance, to language or parenting practices, are considered problematic. As a result, minority children and parents are met with "language tones" (Palludan, 2007) and patterns of cooperation (Bregnbæk et al., 2017) different from those involving majority children and parents, hereby creating and reinforcing processes of exclusion rather than inclusion.

Nature education, we argue, is one area in which such exclusionary processes are at work. Free outdoor play and explorations in "nature" have important roles as cultural practices that are taken for granted in early childhood pedagogies in the Scandinavian countries (Gulløv, 2012; Halldén, 2009; Harju, Balldin, Ekman Ladru \& Gustafson., 2020). This involves strong expectations of 'sameness' (Gullestad, 2002) in children's relations to nature, as children are expected to "naturally" engage in outdoor play in all kinds of weather, and to enjoy it, just as parents are expected to support these practices, for instance by ensuring the right kind of outdoor clothing. Families unfamiliar with the everyday outdoor life of day care institutions and who do not practice specific kinds of outdoor life activities, are described as lacking something. Several nature educators and students interviewed in connection with the research project, including educators from the school garden, use the category "foreign to nature" (naturfremmed) to describe children and families who seldom do outdoor activities, and who, according to the educators, need to be included to ensure equal access to nature. The word "foreign" in this context evokes associations to public discourse about foreigners, that is, people who are not "the same". In other words, discussions about access to nature experiences and nature education become framed by and entangled with societal mechanisms of exclusion. Furthermore, in line with a more general global and national trend, the term naturfremmed reflects an increasing tendency for state agencies and other actors to place the responsibility for problematic societal developments with the parents, creating a need for early intervention in relation to problematic parenting practices (Bregnbæk et al., 2017; Faircloth \& Murray, 2015; Houmøller, 2018). When Peter explained his choice of buying a halal- slaughtered chicken, he described the children involved in the activity as growing up in families of low socio-economic status, who attach great importance to religion. So, to be able to communicate with the parents and include their children in the educational activities of the garden, you need to adapt a bit, he said, adding, "it's a way of showing respect". The choice of words clearly shows that the educational activities in the garden are not by design oriented towards socio-cultural differences related, for instance, to eating habits or religion. In other words, difference is not looked on as a resource to explore and learn from (Parekh, 2006), but as a difficulty to overcome. Although Peter continued his activity as normal after presenting the halal-slaughtered chicken, the discussion about eating rules stole quite a lot of attention from the rest of the activities. So, in an attempt to include the minority children on an equal footing and show respect, Peter paradoxically ended up positioning them as different, or not the same, in terms of relations to nature, eating habits, religion and socio-economic status. This pattern is not specific to this situation or context, but visible in a wide range of nature education activities involving minority children that we observed during the research. While Peter might very well be aware of the ambivalence of his actions - trying to overcome, but actually emphasizing differences - he does not reflect upon it explicitly. Neither does he openly bring out a second ambivalence created by the halal solution: While exchanging the chickens ensures social inclusion in the activity, it also undermines Peter's earlier argument that it is okay to slaughter and eat the first chicken, since it has had a good life in the garden. We do not know what kind of life the second chicken had had, and neither the children, nor visiting students and the researcher, when subsequently discussing the case with Peter, are encouraged to dig deeper into the emotions and reflections related to difficult structural questions concerning the quality of human and animal life that cut across cultures and religions.

In the following, we will explore further the question of ambivalence, pointing to the need to encourage nature and sustainability educators to pay greater analytical and reflective attention to emotional ambivalence.

\section{Sameness in relations to nature, emo- tions of ambivalence}

Before Peter slaughters the chicken, the boy Ahmed approaches the cage and sticks his finger through the wire. The chicken pecks his finger, and Ahmed quickly moves away. [...] After slaughtering the chicken, Peter shows the head to the children. Ahmed turns away, telling Peter that he is afraid of the chicken. Later on, he comes back, moves slowly forward and touches the head of the dead chicken. "Now not scared to touch", he whispers, continuing thoughtfully," it bit me..... I'm not scared anymore". [...] Peter cuts up the dead chicken, showing the children the different parts. Ayla tells him that the chicken doesn't have a name; if it has a name, it will be scared when you hit it and burn it. [...] As Peter shows the eight children how to place the wood to make a fire, he is 'interrupted' by a young rooster approaching the fire, squawking. The children turn to- 
wards the rooster, some screeching and running away from the fire, they look scared, excited and happy at the same time.

(Edited field notes, November 2018)

These field notes constitute a selection of descriptions of numerous different situations in the school garden, in which the emotions and moods arising from the children's interaction with nature, or the more-than-human world, appear to be rife with ambivalence. Fright is mixed with emotions of fascination and disgust; discomfort with joy and attraction; empathy with the presumed feelings of the chicken with its no-name 'identity' as food. Yet, only seldom have we seen nature educators pay explicit attention to the ambivalences of children's experiences in and with nature. In their discourse about what happens in the garden, they emphasize the positive emotions of joy, play and curiosity, and if they discuss negative emotions, their focus is on the social background of the children, not on the relations between the children and the animals or garden.

On the one hand, it appears obvious that some of the children's ambivalent emotions in the garden are linked to tensions between the norms of their home and the norms of the day care institution. This seems to be the case described in the introductory field note, in which Aysha's sudden worry about her dirty clothes and hands appears to reflect conflicting understandings of children and dirt between the day care institution and her home. While many social educators and Danish middle class parents appear to associate outdoor play with notions of a good childhood - autonomous free play, being outdoors and getting dirty - to some immigrant parents this kind of early childhood education is at best unfamiliar, and at worst evokes what Trnka, Dureau \& Park (2013, p. 19) refer to as "embodied alienation" (Trnka et al., 2013, p. 19)..$^{5}$ The reaction of the early childhood educator who is accompanying Aysha in the garden suggests that she expects Aysha to adapt to the cultural understanding of dirt that characterizes outdoor education in Denmark. The upshot is that the expectation of sameness, and the attaching of a high moral value to being outdoors, prevent space being made for children's differentiated and ambivalent emotional reactions to outdoor experiences - e.g., the way in which Aysha's joy of interacting with an earthworm is accompanied by feelings of discomfort with the experience of wet soil on her hands and of getting her jacket dirty.

On the other hand, the ambivalent emotions of the children as they interact with a living and a dead chicken, seem to reflect a more general tension in relations between children and the more-than-human world. In the literature on early childhood sustainability education, recent writings inspired by new material theories have criticized romanticized notions of children and nature and pointed to the messy entanglements of nature and culture in children's worlds (Taylor, 2013; Taylor \& Giugni, 2012). However, we have found that literature pays little attention to the emotional ambivalences that are discussed in other domains of research occupied with learning about and studying everyday life. Mason, for instance, describes the ambivalent emotions arising in embodied and sensuous interactions with, for instance, animals or places, proposing that contradictory thinking is "not annoying indecision or a temporary conflict that will ultimately be resolved, or a device for success- ful being "in denial", but it is instead a steady and sometimes charged state, a normal way of being" (Mason, 2018, p. 56). Social psychological research inspired by critical theory has developed the concept of everyday consciousness, pointing to the processes through which adults deal with ambivalence in their everyday life (Becker-Schmidt \& Knapp, 1987; Leithäuser, 1976), and learning theories focusing on transformative learning describe the learning potentials of bringing attention to and reflecting on such ambivalences (Illeris, 2004).

These writings do not address children, yet we propose that it might be useful to further explore, theoretically and empirically, the emotional ambivalences of experiences of difference and otherness in the context of early childhood, and the educational openings for inclusive early childhood sustainability education that these ambivalences may constitute. Our analysis has suggested that the cultural expectations of sameness in relations to nature described above are responsible for a lack of attention to, or even exclusion of, "other" kinds of nature relations, including the strong ambivalence in emotional relations to more-than-human others. This may hinder the attention to diverse ways of being in nature, which could be a key to developing further the content of early childhood sustainability education and make it more inclusive.

\section{Conclusion}

In this article, we have argued that although sustainability as a concept and sustainability education as described within the SDGs agenda are united in their attention to social inclusion and ecological sustainability, in educational practice, tensions sometimes arise between the two concerns. In the Scandinavian context, where the values of equality are often conceived of as "sameness" in the interactions of everyday life, and are combined with powerful cultural images of the good childhood as linked to playful outdoor activities and a familiarity with nature, attempts to address social inclusion in early childhood sustainability education appear to overlook societal mechanisms of exclusion. This, we have argued, becomes a barrier for socially inclusive sustainability education, but it also prevents attention being paid to the emotional ambivalence associated with being in nature. We propose that such educational attention to ambivalence in terms of socio-cultural as well as socio-material relations would constitute one important response to the challenge of relating sustainability education and social inclusion to each other. There is, however, a need for more research into this educational potential, preferably in dialogue with practitioners. 


\section{Notes}

1 "Social educator" is the official Ministry of Education translation of the Danish term "paedagog"; a member of staff trained in pedagogical theory and practice, including the care of younger children.

2 All names are pseudonyms.

3 Largely achieved in terms of numbers as $97 \%$ of children in Denmark attend early childhood education. According to Danmarks Statistik, in $201397 \%$ of 3-5-year-old children attended early childhood education (dst.dk), and according to staff members at Danmarks Statistik, this number appear relatively stable.

4 As for instance indicated by the establishment of a National Research Centre for Inclusion and Exclusion (NVIE) in 2005 by the Ministry of Education and two university colleges.

5 This argument is based on unpublished analysis of interviews with refugee parents and social educators with minority background carried out as part of a research project on the encounter between refugee families and early childhood (2016-2018) by Susanne Bregnbæk and Nanna Jordt Jørgensen.

\section{Acknowledgement}

We are indebted to our collaborators in Københavns Skolehaver, whose hospitality, openness and constructive reflections have been of great value to our research. Furthermore, we thank Karen Bollingberg, Dorte Celinder, Birgitte Damgaard and Tejs Møller, as well the editors and reviewers of the journal for their valuable comments on the analysis and text.

\section{References}

Becker-Schmidt, R. \& Knapp, G.-A. (1987). Geschlechtertrennung - Geschlechterdifferenz. Suchbewegungen sozialen Lernens. Bonn: Verlag Neue Gesellschaft GmbH.

Boldermo, S. \& Ødegaard, E. (2019). What about the Migrant Children? The StateOf-The-Art in Research Claiming Social Sustainability. Sustainability, 11(2), 459. https://doi.org/10.3390/su11020459

Børne- og Socialministeriet (2018). Den styrkede padagogiske lereplan: Rammer of indhold. Access on 20.01.2020 https://emu.dk/dagtilbud/forskning-og-viden/ den-styrkede-paedagogiske-laereplan-rammer-og-indhold

Børne- og Undervisningsministeriet (2020). Inklusion. Access on 20.01.2020 https:/ /www.uvm.dk/dagtilbud/paedagogiske-redskaber-og-rammer/inklusion

Bregnbæk, S., Arent, A., Martiny-Bruun, A. \& Jørgensen, N. J. (2017). Statens eller familiens børn? Tvang og omsorg i mødet mellem nytilkomne familier og danske daginstitutioner. Forskning i Pedagogers Profession og Uddannelse, 1(2), 14.

Bruun, M. H. (2018). Social Imaginaries and Egalitarian Practices in the Era of Neoliberalization. In S. Bendixen, M. B. Bringslid \& H. Vike (eds.), Egalitarianism in Scandinavia. Historical and Contemporary Perspectives (p. 135-155). Springer International Publishing. https://doi.org/10.1007/978-3-319-59791-1_6

Bundgaard, H. \& Gulløv, E. (2008). Forskel og fallesskab: minoritetsbørn i daginstitution. Copenhagen: Hans Reitzels Forlag.

Coffey, A. \& Atkinson, P. (1996). Making sense of qualitative data: Complementary research strategies. The Lancet (Vol. 42). Thousand Oaks: SAGE Publications.

Davis, J. (2009). Revealing the Research "Hole" of Early Childhood Education for Sustainability: A Preliminary Survey of the Literature. Environmental Education Research, 15(2), 227-241. https://doi.org/10.1080/13504620802710607

Edlev, L. T. (2015). Natur og miljø i padagogisk arbejde. Købehavn: Munksgaard.

Edlev, L. T. (2016). Drabets didaktik. Kaskelot, 211, 30-33.

Ehn, B. \& Löfgren, O. (2010). Kulturanalyser. Århus: Forlaget Klim.

Ejby-Ernst, N., Seidler, P. H., \& Sørensen, V. (2018). Inddragelse af naturen i arbejdet med born og unge $i$ udsatte positioner - med naturaktiviteter som en integreret del af indsatsen. København: Københavns Universitet og 15.juni Fonden.

Faircloth, C. \& Murray, M. (2015). Parenting: Kinship, expertise, and anxiety Journal of Family Issues, 36(9), 1115-1129. https://doi.org/10.1177/0192513X14 533546

Gullestad, M. (2002). Invisible Fences: Egalitarianism, Nationalism and Racism. Journal of the Royal Anthropological Institute, 8(1), 45-63. https://doi.org/10.1111/ 1467-9655.00098

Gulløv, E. (2012). Den tidlige civilisering: en flertydig bestræbelse. In L. Gilliam \& E. Gulløv (eds.), Civiliserende institutioner: om idealer og distinktioner i opdragelse. Aarhus: Aarhus Universitetsforlag.

Halldén, G. (2009). Naturen som symbol för den goda barndomen. Stockholm: Carlssons.

Hamre, B. \& Larsen, V. (2016). Inklusion, udsathed og tverprofessionelt samarbejde. Frederiksberg: Frydenlund Academic.
Harju, A., Balldin, J., Ekman Ladru, D. \& Gustafson, K. (2020). Children's education in 'good' nature: Perceptions of activities in nature spaces in mobile preschools. Global Studies of Childhood. https://doi.org/10.1177/2043610619900519

Hedefalk, M., Almqvist, J. \& Östman, L. (2015). Education for sustainable development in early childhood education: a review of the research literature. Environmental Education Research, 21(7), 975-990. https://doi.org/10.1080/13504622.20 14.971716

Houmøller, K. (2018). Making the invisible visible? Everyday lived experiences of 'seeing' and categorizing children's well-being within a Danish kindergarten. Childhood, 25(4), 488-500. https://doi.org/10.1177/0907568218783810

Husted, M. \& Frøkjær, T. (2019). Natur og bæredygtighed i daginstitutionen pædagogik for bæredygtighed i praksis. Tidsskrift for Nordisk barnehageforskning, 18(1). https://doi.org/10.7577/nbf.3229

Husted, M. \& Tofteng, D. M. B. (2014). Critical Utopian Action Research. In D. Coghlan \& M. Brydon-Miller (eds.), The SAGE Encyclopedia of Action Research (p. 230-232). Los Angeles, London, New Delhi, Singapore \& Washington: SAGE Publications.

Illeris, K. (2004). Transformative Learning in the Perspective of a Comprehensive Learning Theory. Journal of Transformative Education, 2(2), 79-89. https://doi.org/1 $0.1177 / 1541344603262315$

Jørgensen, N. J. (n. d.). Bæredygtighed og global udlighe i uddannelsesperspetkiv. In J. G. Lysgaard \& N. J. Jørgensen (eds.), Baredygtighedens padagogik. Forskningsbaserede perspektiver på uddannelse, padagogik og baredygtig udvikling. Frederiksberg: Frydenlund.

Jørgensen, N. J. \& Martiny-Bruun, A. (2019). Painting trees in the wind: socio-material ambiguity and sustainability politics in early childhood education with refugee children in Denmark. Environmental Education Research, 1-14. https://doi.org/10. $1080 / 13504622.2019 .1602755$

Læssøe, J. (n. d.). Dynamisk samspilsforståelse/helhedsorienteret erkendelse. In J. G. Lysgaard \& N. J. Jørgensen (eds.), Baredygtighedens padagogik. Forskningsbaserede perspektiver på uddannelse, padagogik og baredygtig udvikling. Frederiksberg: Frydenlund.

Larsen, V. \& Jørgensen, N. J. (2017). Review of Danish Research on Social Inclusion in Early Childhood Education. København.

Leithäuser, T. (1976). Formen des Alltagsbewusstseins. Frankfurt: Campus Socialpsykolog

Low, S. M. \& Merry, S. E. (2010). Engaged Anthropology: Diversity and Dilemmas. Current Anthropology, 51(2), 203-226. https://doi.org/10.1086/653837

Mason, J. (2018). Affinities: potent connections in personal life. Wiley.

Mauritzon, L. (2018). Vild pedagogik. Magasin Måltid, 5, 68-73.

Ministry of Education Science and Culture (2011). The Icelandic National Curriculum Guide for Preschools. Access on 20-01-2020. http://chrodis.eu/good-practice/ icelandic-national-curriculum-guides-preschools-compulsory-schools-upper-secondary-schools-health-wellbeing-one-six-fundamental-pillars-education-iceland/ Nielsen, G. B. \& Jørgensen, N. J. (2018). Engagement beyond critique? Anthropological perspectives on participation and community. Conjunctions. Transdisciplinary Journal of Cultural Participation, 5(1). https://doi.org/10.7146/tjcp.v5i1.1052 89

Nielsen, K. A. \& Svensson, L. (2006). Action Research and Interactive Research: beyond practice and theory. Maastricht: Shaker Publishing.

Palludan, C. (2007). Two tones: The core of inequality in kindergarten? International Journal of Early Childhood, 39(1), 75-91. https://doi.org/10.1007/BF03165949 Parekh, B. (2006). Rethinking Multiculturalism. Cultural Diversity and Political Theory. Hampshire/New York.: Palgrave Macmillan. https://doi.org/10.1007/978-0-23 $0-20425-6$

Pedersen, H. (2019). The Contested Space of Animals in Education: A Response to the "Animal Turn" in Education for Sustainable Development. Education Sciences, 9(3), 211. https://doi.org/10.3390/educsci9030211

Prins, K. M. (2019). På jagt efter det demokratiske. En pragmatisk kulturanalyse af muligheder og begransninger for borns demokratiske erfaringer $i$ daginstitutionen. Roskilde University.

Rytter, M. (2018). Writing Against Integration: Danish Imaginaries of Culture, Race and Belonging. Ethnos, 1-20. https://doi.org/10.1080/00141844.2018.1458 745

Schnack, K. (2000). Action competence as a curriculum perspective. In B. B. Jensen, K. Schnack \& V. Simovska (eds.), Critical Environmental and Health Education research issues and challenges (p. 107-126). Research Centre for Environmental and Health Education, the Danish University of Education.

Skolverket (2018). Läroplan för förskolan. Sweden.

Skytte, E. (2019). Ud i naturen - ind i fallesskabet. København: Akademisk Forlag. Somerville, M. \& Williams, C. (2015). Sustainability education in early childhood: An updated review of research in the field. Contemporary Issues in Early Childhood, 16(2), 102-117. https://doi.org/10.1177/1463949115585658 
Sparrman, A., Westerling, A., Lind, J., \& Dannesboe, K. I. (2016). Doing Good Parenthood: Ideals and Practices of Parental Involvement. Cham: Palgrave Macmillan. https://doi.org/10.1007/978-3-319-46774-0

Sustainia \& Realdania (2018). Klima100. Access on 20.01.2020. https://realdania. $\mathrm{dk} /$ projekter/klima 100

Taylor, A. (2013). Reconfiguring the Natures of Childhood. New York: Routledge.

Taylor, A. \& Giugni, M. (2012). Common Worlds: Reconceptualising Inclusion in Early Childhood Communities. Contemporary Issues in Early Childhood, 13(2), 108-119. https://doi.org/10.2304/ciec.2012.13.2.108

Trnka, S., Dureau, C. \& Park, J. (2013). Introduction. Senses and Citizenship. In S. Trnka, C. Dureau \& J. Park (eds.), Senses and Citizenship: Embodying Political Life. New York: Routledge. https://doi.org/10.4324/9780203374658

United Nations. (2015). Education - United Nations Sustainable Development Goals. Access on 20.01.2020. https://www.un.org/sustainabledevelopment/education/

WCED (1987). Our Common Future: Report of the World Commission on Environment and Development. Oxford: Oxford University Press.

\section{Nanna Jordt Jørgensen}

is Associate Professor, $\mathrm{PhD}$, at University College Copenhagen. Her research interests revolve around the agency of children, young people and their fami- lies in relation to education, sustainability, development and immigration. In recent years, she has been involved in ethnographic research on the encounter between refugee families and early childhood institutions in Denmark and in a larger action research project on Education for sustainability in early childhood (2018-2020).

\section{Katrine Dahl Madsen}

is Associate professor, $\mathrm{PhD}$, at University College Copenhagen. She has worked with sustainability education research within schools and more recently with a focus on early childhood education, among others in the research project Health promoting sustainable school development and currently in a larger action research project Education for sustainability in early childhood (2018-2020)

\section{Mia Husted}

is Reader, $\mathrm{PhD}$, at University College Copenhagen. She works with early childhood education with an engagement to action research and the relationship between research and development, learning or change within the welfare professions in Denmark. She is currently leading a larger action research project Education for sustainability in early childhood (2018-2020). 